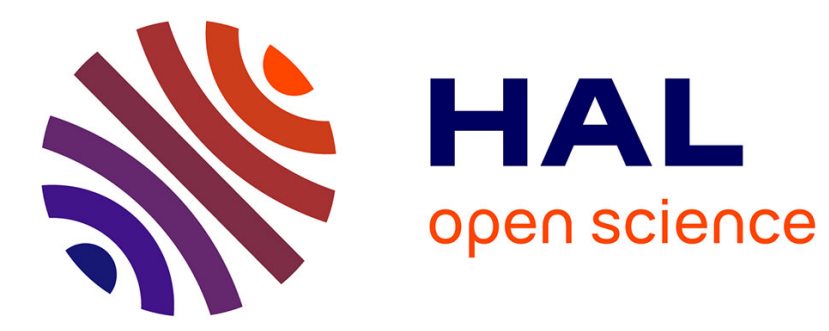

\title{
Seeing Like a Refugee Agency: A Short History of UNHCR Classifications in Central Africa (1961-2015)
}

Joel Sebastien Glasman

\section{To cite this version:}

Joel Sebastien Glasman. Seeing Like a Refugee Agency: A Short History of UNHCR Classifications in Central Africa (1961-2015). Journal of Refugee Studies, 2017, 30 (2), pp.337-362. $10.1093 / \mathrm{jrs} /$ few044 . halshs-01636942

\section{HAL Id: halshs-01636942 \\ https://shs.hal.science/halshs-01636942}

Submitted on 21 Nov 2017

HAL is a multi-disciplinary open access archive for the deposit and dissemination of scientific research documents, whether they are published or not. The documents may come from teaching and research institutions in France or abroad, or from public or private research centers.
L'archive ouverte pluridisciplinaire HAL, est destinée au dépôt et à la diffusion de documents scientifiques de niveau recherche, publiés ou non, émanant des établissements d'enseignement et de recherche français ou étrangers, des laboratoires publics ou privés. 


\title{
Seeing Like a Refugee Agency: A Short History of UNHCR Classifications in Central Africa (1961-2015)
}

\author{
JOËL GLASMAN \\ Humboldt Universität zu Berlin, Germany \\ glasmanj@staff.hu-berlin.de
}

MS received August 2015; revised MS received November 2016

\begin{abstract}
This article looks at the evolution of international refugee protection, using the refugee classifications of UNHCR as an entry point. It is argued that, since the creation of the United Nations High Commissioner for Refugees (UNHCR), access to refugee aid has been globalized but has also become more and more stratified. The UNHCR has expanded its activities beyond the frontiers of Europe, but has also tailored aid for specific groups. This is because protection work increasingly articulates different modes of classifying refugees. Three modes of ordering are explored here in the Central African case: the legal approach, the labour (or developmental) approach and the basic needs (or vulnerability) approach. These modes refer to different regimes of action, different actors of protection and eventually different subjectivities. Each mode of classification, it is argued, is the product of a specific period of the UNHCR's history.
\end{abstract}

Keywords: Classification, Africa, UNHCR, history

\section{Introduction}

In 2014, 189,802 people left the Central African Republic. Thousands crossed the border to Cameroon by car, truck or foot, to the small town of Kenzou. Once there, they applied for refugee protection. Gathering on the dusty football field of Kenzou, near the police station, they waited for a chance to be interviewed by United Nations High Commissioner for Refugees (UNHCR) staff. ${ }^{1}$ They waited for days, sometimes weeks, before they finally managed to access the small plastic tables where UNHCR clerks classified them based on their names, sex, age, place of birth, date of arrival, marital status, size of their household, etc. ${ }^{2}$ After the long hours of waiting in the heat of the football field, the registration process was relatively brief and smooth. Nevertheless, the atmosphere at the plastic tables was tense. People argued, contested and at times yelled at each other, sometimes to the point that police 


\section{Glasman}

forces intervened and interrupted the process. This was not just because the new arrivals were exhausted after having been harassed by rebels, custom officers and gendarmes ${ }^{3}$; rather, after the long journey from places as far away as Carnot, Berberati and Nando, they understood that the few minutes spent with the registration clerk would determine which category they would be assigned to and would shape the next chapter of their life. They knew that classifications matter.

This article argues that, over the last 50 years or so, international refugee protection has become increasingly stratified. International organizations have specialized, rationalized and individualized intervention - and resource allocation. Access to international aid has been broadened, but aid itself has become tailored for specific groups. Stratification has occurred as the UNHCR has expanded its action beyond its original mandate-beyond the borders of Europe and beyond the boundaries of the 1951 Refugee Convention.

In order to grasp this double movement of expansion and stratification, it is necessary to examine specific cases. Most of the examples discussed below are chosen from a broad Central African region-arguably an arbitrary choice (a similar argument could be made based on other cases), but a convenient one since this region has received UNHCR assistance throughout the last 60 years. ${ }^{4}$ Central African countries were among the first to receive UNHCR assistance after independence in the early 1960s and continue to use up an important share of the UNHCR budget today (UNHCR 2015: 82).

\section{Fifty Shades of Refugees: Why Classifications Matters}

Refugee classification is an emblematic illustration of Pierre Bourdieu's insight that life chances are shaped not only by 'class struggles', but also by 'classification struggles' (Bourdieu 1979). Refugee classifications determine who qualifies for protection under international law, as well as the quality of the relief aid. Access to refugee camps, tents, food rations and basic items depend on the categories attached to a refugee's name in UNHCR databanks, identity documents and ration cards. Refugee status, family size, special needs: categories shape a refugee's chances in life, the opportunities and constraints. They are important not only for the refugees themselves, but for the system of protection as a whole. Need assessment, programme planning and resource allocation are all based on refugee classifications. The same categories ('refugee', 'single head of household', 'T4', etc.) inform interactions between aid beneficiaries and aid workers, aid workers and headquarters, headquarters and donors. They tie together actions, persons and places, thus making collective action possible. They link the micro level of refugee registration in the field to the macro level of UNHCR global policy.

Yet classifications are poorly understood. Most of the time, we simply overlook them. We use refugee classifications to describe the world, assuming that they are as natural and universal as the world itself. We look at reality 
through the lens of the UNHCR, without even noticing that we are doing so. Refugee classifications are a black box of refugee protection; they play a key role in the entire process, but they function virtually automatically and are barely questioned..$^{5}$ They are so ubiquitous in the protection sector that it is almost impossible not to rely on and use them. Refugee statistics are a good example: the 189,802 refugees mentioned in the opening sentence of this text is an aggregated figure based on classifications provided by the UNHCR in Kenzou and other similar towns in the African rainforest. ${ }^{6}$

There are good reasons for this, of course. Protection clerks hardly have the luxury of engaging with ontological questions. When registering refugees, they do not usually question classifications. This does not mean that they are naive about their tools. I met a Cameroonian protection clerk, Alain, ${ }^{7}$ who, as a sharp observer and member of the same vernacular group as the refugees he was helping, could hold forth for hours about the sophisticated social distinctions of Fulani society. Yet, as a UNHCR staff member and lawyer, he applied the narrow categories of refugee protection in his work. Aid workers do not question the nature of refugee classifications while addressing their needs, anymore than a paediatrician questions the nature of thermometers while examining a sick child. The same is true when institutional partners (United Nations agencies, ministry officials, non-governmental organizations (NGOs), etc. $)^{8}$ meet in headquarters, or when UNHCR staff in Geneva aggregate statistical data. Aid workers tend to take social categories for granted, as do consultants, journalists and social scientists.

There is a notable exception to this rule: namely critical anthropologists and those they have inspired. In the last 30 years, these scholars have studied categories as social constructions. Barbara Harrell-Bond has argued that the concept of refugee is 'an artificial category maintained more for the convenience of donors than for the people involved' (Harrell-Bond 1986: xvi). Gérard Noiriel has shown that the category of refugee has its historical roots in the localized context of the French Revolution (Noiriel 1991), while Liisa Mallki has revealed how, since World War II, humanitarian experts and refugee studies have essentialized it (Malkki 1995b: 496).

Yet, even more importantly, anthropologists have shown that refugees themselves have challenged refugee classifications. While classifications may shape refugees' subjectivities, this happens through a dynamic process of criticism, adaptation and rejection (Fresia 2002; Corbet 2008; Dedenis 2006; Tallio 2007; Inhetveen 2010; Turner 2010; Jaji 2011; Jansen 2011; Ringel 2011). Far from passively waiting to be labelled, refugees try to make the most of classifications. They adapt their testimony, borrow identity documents and accumulate ration cards. In Kenzou, some refugees sought, and many obtained, the protection of two different international institutions at the same time: the UNHCR and the International Organization for Migration - a double classification that is theoretically impossible under international law. ${ }^{9}$ 


\section{Glasman}

Critical anthropology has taken a decisive step towards a better understanding of refugee classification. However, in some cases, the critical analysis loses sight of historical contingencies. The structural critic attempts to uncover power relations hidden behind classification regimes, but misses the historicity of refugee protection. There is a tendency in the critical literature to reduce classification to domination. In the words of Jean-Pierre Godding, for instance: 'The UNHCR considers the refugees more as statistical units, numbers in an administration, perhaps as animals in a zoo' (Godding 1997: 1). This criticism has been instrumental to denaturalizing refugee classifications. However, it is necessary to go further now to grasp the different rationalities at work here.

James Scott's notion of 'legibility' is useful in this regard. In Scott's view, a central problem of the modern state is that it arranges populations in order to simplify state functions such as taxation and conscription (Scott 1998). Scott focuses attention on categories, formats, processes of standardization and rationalization. Similarly, this article focuses on the ways in which the UNHCR arranges populations according to its mandate to protect, and on how UNHCR expertise translates complex, illegible and multiple local claims into standard categories that can be recorded, compared and used. Refugee classifications are like abridged maps of societies, representing the slices of reality that are of interest to international institutions. However, refugee classifications are more than just maps; they shape reality, have juridical and material consequences, and mediate between discourses and everyday actions.

In this article, I suggest that international refugee protection articulates different ways of making societies legible - let us call them 'modes of ordering'. ${ }^{10}$ I distinguish between three modes of ordering: a legal approach, a labour or developmental approach and a basic needs or vulnerability approach. (This does not mean that there are only three modes of ordering refugees, of course, but identifying three suffices to make the point that there is more than one. A truly exhaustive study would have to address other modes of ordering, such as family ties, gender, security, etc.) These modes of ordering have a lot in common: they claim to be universally applicable, non-political and to limit the arbitrariness of state sovereignty. They claim to be objective, in the sense of making it possible to take action towards establishing norms, standards or categories that do not depend on who applies them. They are based on categories that enable quantification and evaluation (i.e. number of refugees, hours worked, items distributed, etc.). Moreover, they all mark a clear distinction between protectors and protected. ${ }^{11}$

However, these three modes of ordering refer to different terminologies, actors, methods and subjectivities. They emerged from different rationales, problems and places. They cannot all be traced back to a single explanatory principle, 'in last instance' - whether it be 'neo-colonialism', 'neo-liberalism', 'sovereignty' or 'biopower' (Harrell-Bond 1986; Hyndman 2000; Barnett 2011; Agier 2008; Scalettaris 2013; Hammerstad 2004). There is no essence to refugee protection, no single unifying logic of classification. Although they 
are distinct from one another, the three modes of ordering do not constitute homogeneous domains. Rather, they constitute different modes of ordering refugees' problems: various ways of articulating principles, practices and people. They form specific knowledge about refugees, about how they behave and how to relate to them (Pols 2003). ${ }^{12}$ They stand for different ways in which international organizations connect the 'problem of refugees' at the global level with the specific fate of individuals.

Let us consider the classification table included in the most well-known UNHCR manual, the Handbook for Emergencies (see Figure 1). At first glance, the table is a coherent grid of categories. To use Scott's terminology, this classification makes complex emergencies legible. The terminology used in the table is consistent with the advice set forth in the Handbook's almost 600 pages, suggesting 'universal standards' to address the 'global problem of refugees' on a 'worldwide' scale. A second look, however, reveals different modes of ordering those in need of protection: there are legal categories ('asylum seeker', 'internally displaced person (IDP)', 'refugee', etc.), professional categories ('student', 'miner', 'nurse', 'weaver', etc.), categories of vulnerability ('disabled', 'blind', 'deaf', etc.), as well as hybrid categories ('traditional leader', 'traditional healer', 'unaccompanied elder', 'woman at risk', etc.). This classification system, in a document meant to guide daily practices, is the result of more than 50 years of UNHCR experience. It is the sedimentation of various layers of history. Consequently, its historicity deserves greater attention.

\section{From Migrants to Refugees: Ordering through Law}

Refugee protection was initially considered a task for lawyers. Protecting refugees meant giving legal assistance. When the UNHCR was established in 1951, its mandate was to advocate international refugee law. The UNHCR did not provide humanitarian relief, but juridical advice. UNHCR staff identified refugees, distributed travel documents, assisted refugees in obtaining the legal statuses provided by states, advocated for their rights and pushed for the normalization of these procedures (Loescher 2000; Hanhimäki and Elie 2008; Barnett 2011; Gatrell 2013).

Originally, the UNHCR was also limited to protecting European displaced persons. However, by the late 1950s, the number of refugees fleeing from the aftermath of World War II and from the Soviet bloc had decreased. There was little left for UNHCR to do in Europe, and all of the major crises were now happening outside its jurisdiction. In Africa, several thousand people were on the run, yet they were not refugees in the UNHCR sense, since the 1951 Convention relating to the status of refugees restricted the definition of refugees to European refugees fleeing from events that occurred before 1951. Africans fleeing from colonial domination were not considered refugees, nor were those fleeing the aftermath of independence. As a result, during the 1960s and 1970s, the UNHCR pushed for the expansion of refugee law. 

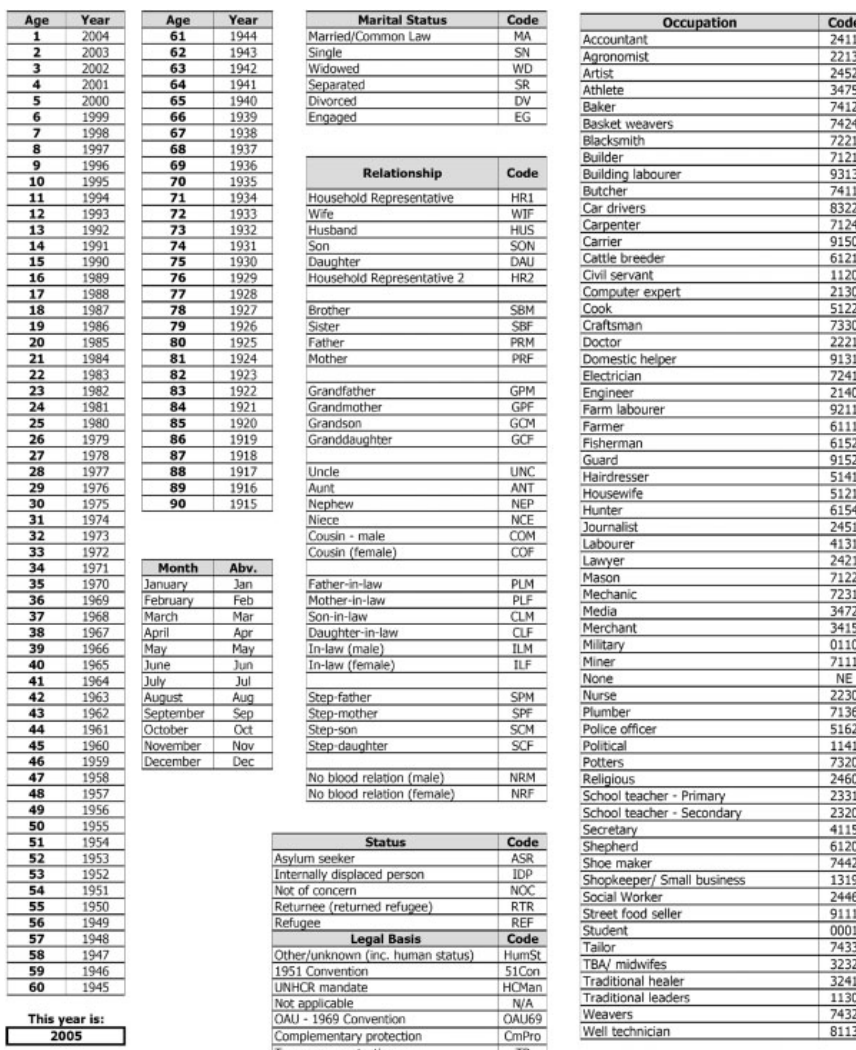

Cartile breed

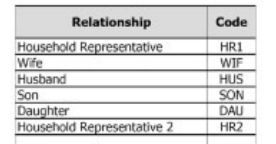

Civil servant

Cook
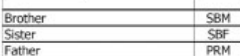

\begin{tabular}{|l|l|}
\hline Father & PRM \\
\hline Mother & PRF \\
\hline
\end{tabular}

Grandfather
Grandmother

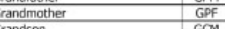

$\mathrm{GCM}$

GCF

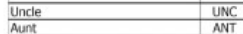

Aunt

\begin{tabular}{l}
\hline Nephew \\
\hline Niece
\end{tabular}

Cousin - male

Cousin - male

Father-in-law

Month Abv.

\begin{tabular}{|l|l|}
\hline Manuary & Jan \\
\hline February & Feb \\
\hline
\end{tabular}

\begin{tabular}{l|l}
\hline March & Mar \\
\hline Aaril & Aor
\end{tabular}

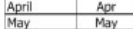

Mother-in-law

Son-in-law

Daughter-in-law

In-law (male)

Step-fother

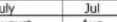

Sugust

\begin{tabular}{lll}
\hline October & Oct \\
\hline
\end{tabular}

Nowember Nov

$\frac{\text { Step-moth }}{\text { Step-son }}$

Step-daughte

SCF

\begin{tabular}{|l|l|}
\hline No blood relation (male) & NRM \\
\hline No blood relation (female) & NRF \\
\hline
\end{tabular}

Doctor

Domestic helper

Electrician

Farm labourer

Farmer

Guard

Hairdresser

Housewife

\begin{tabular}{|l|l|}
\hline Hunter & 6154 \\
\hline Journalist & 2451 \\
\hline
\end{tabular}

Labourer

Lawyer

Mason

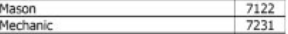

Media

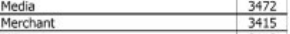

Militar

\begin{tabular}{l}
\hline Miner \\
\hline None \\
\hline Nurse \\
\hline Plumber \\
\hline
\end{tabular}
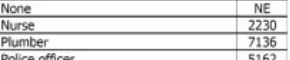

Political

Potters

Religious

School teacher - Primary

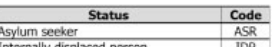

Secretar

Shepherd

\begin{tabular}{|l|l|}
\hline 6120 \\
\hline 7442 \\
\hline
\end{tabular}

Shopkeeper/Small business

Street food seller

\begin{tabular}{ll}
\hline Returnee (returned refugee) & RTR \\
\hline
\end{tabular}

Student

TRA/ midwifes

Traditional healer

Traditional leaders

other/unknown
1951 Convention

Wot appicable

Weavers

Weall technician
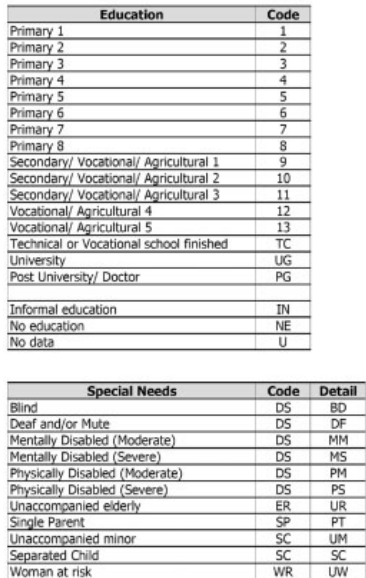

Figure 1

$$
\begin{aligned}
& \text { Separated Child } \\
& \text { Woman at risk }
\end{aligned}
$$

A Classification Code Used by the UNHCR

Sample codes from: UNHCR (2007), Handbook for Emergencies, 3rd edn, p. 175. 
Africa, of course, had a long history of displacement. Forced migration was a banal reality in pre-colonial African societies ${ }^{13}$ : in the nineteenth century, it had been fuelled by the European slave trade on the Atlantic coast, the Fulani Jihad in Northern Nigeria, Sudanese warriors' raids in the Lake Chad area and Zulu expansion in South Africa, while, in the twentieth century, people fled from imperial conquest, colonial repression, army conscription, forced labour, epidemics and famines (Harms 1981; Cordell and Perouse de Montclos 2002; Guichaoua 2004).

Massive as they were, these displacements were not viewed through the lens of refugee law. Colonial administrators considered migrants a threat to their authority. They complained about 'detribalization', 'floating populations' and 'vagabonds'. ${ }^{14}$ They described migration as pathology. ${ }^{15}$ Conversely, critics of colonialism considered displacement a sign of colonial brutality. A talented journalist like Albert Londres was able to write powerful pages about forced migration without mentioning refugees. He described the permanent 'exodus' produced by colonialism: '2.6 million Blacks from French West Africa, and many hundreds of thousands from French Equatorial Africa left the French territory' (Londres 2008 [1929]: 108, 218). ${ }^{16}$ But he did not consider them refugees as defined by international law.

Not much had changed by the early 1950s. The 1951 Refugee Convention did not apply to the situation in Africa, so the UNHCR sought other ways to intervene. The High Commissioner argued that UNHCR statutes were broader than the Convention's definition, since the latter related to refugees as individuals, while the statutes related to 'groups and categories of refugees'. He pushed the idea of 'good offices', according to which the UNHCR could provide material assistance to persons beyond the Convention's definition. ${ }^{17}$ In 1961, this procedure was formalized in a Resolution of the United Nations General Assembly. ${ }^{18}$ A precondition was that states wanting help from the UNHCR were expressly required to lend their 'good offices'. Soon after gaining independence, the heads of states of Burundi and Congo engaged in this procedure.

For the UNHCR, the situation in the Great Lakes region was illegible (in Scott's sense of the term), not only because the agency lacked regional experience and had no staff from Africa itself, ${ }^{19}$ but also because the mass displacements in the area were embedded in a large and complex concentric movement of labour migrants, farmers and seasonal workers. ${ }^{20}$ All of the countries in the region had received several thousand migrants. Around 14 per cent of the population of Ruanda-Urundi was living in neighbouring countries. In some parts of Uganda, foreigners represented more than a quarter of the population. Around 500,000 Rwandans and Burundians lived in Uganda, and another 155,000 in Tanganyika (Chretien 1978: 72-73; Chrétien 2000: 243-244; Guichaoua 2004: 112).

The UNHCR considered it too difficult to undertake individual assessments in the region. As a result, it introduced the notion of prima facie refugees: a way to assist refugees through 'good offices' without normal 
determination procedures - and without providing full legal protection. Thus, it created a specific category of refugees for non-Europeans - a distinction that the High Commissioner fully accepted: the 'old refugees' in Europe had needed legal protection, while the 'new refugees' in the 'Third World' primarily needed 'material assistance'. ${ }^{21}$ In this way, the juridical category of prima facie refugee distinguished African refugees from European refugees.

Parallel to this, attempts were made to broaden the scope of the 1951 Refugee Convention. In 1967, states agreed on a protocol relating to the status of refugees that removed the words 'as a result of events occurring before 1 January 1951' from the definition of refugee, so that non-European refugees could also benefit from the Convention. However, the UNHCR still considered refugees in Africa to be 'too numerous, dispersed and poor to make individual assessments necessary for Convention refugee designation' and continued to apply prima facie and 'good offices' procedures in the region (Holborn 1975: 440).

African heads of states organized a response. They believed that the 1951 Refugee Convention was based on European values and felt the need for a regional instrument. The 1951 definition of refugee was in fact a product of the European tradition, emphasizing political and civil rights over cultural, economic and social rights (Noiriel 1991). The 1951 Convention defined refugees as persons fleeing due to legitimate fears of persecution, by which they meant 'reasons of race, religion, nationality, membership of a particular social group or political opinion'. ${ }^{22}$ The list excluded disease, poverty, natural catastrophe, civil unrest, war or state collapse as entitling individuals for refugee status. Political and civil oppression were seen as a legitimate reason for flight, while material deprivation, drought and hunger were not (Hyndman 2001; Cambrezy 2007; Barnett 2011; Hathaway and Foster 2014).

In 1969, the Assembly of Heads of State and Government, the highest organ of the Organization of the African Union (OAU), adopted a new convention specifically for refugee problems in Africa. The first article of the 1969 OAU Convention replicated the definition of refugee of the 1951 Convention in terms of indicating political and civil forms of persecution as reasons for flight. However, Article 2 broadened the notion of refugee to also include

every person who, owing to external aggression, occupation, foreign domination or events seriously disturbing public order ... is compelled to leave his place of habitual residence in order to seek refuge in another place outside his country of origin or nationality.

This new definition expressly incorporated generalized violence as a cause for flight (Rutinwa 2002; Okoth-Obbo 2001; Sharpe 2012).

Some 20 years after the creation of the UNHCR, international refugee law remained the dominant mode for ordering refugees. International law began by distinguishing refugees from the larger groups of migrants and then 
multiplied the categories of protection. Some refugees were recognized by national state law; others were refugees under the 1951 Convention or under the 1969 OAU Convention; still others were considered prima facie refugees under the UNHCR Statute ('mandate refugees'). In the words of Jennifer Hyndman, this created an 'uneven geography of refugee definitions in international law' (Hyndman 2001: 48).

Not only did 'refugee' encompass several definitions, but a number of other legal categories also competed to include displacement under international and national law: IDPs, asylum seekers, detainees, stateless persons, evicted persons, illegal migrants, war victims, evacuees, expellees, repatriates, returnees and so forth. Of course, people on the run might qualify for several different juridical statuses in succession. For example, having been forced to flee from home while remaining in the same country, they may have become IDPs, only to then pursue their flight into the neighbouring country, thus becoming asylum seekers; there, they may have been recognized first as mandate refugees and later as refugees according to the 1969 OAU Convention and so on. The prism of law made forced displacement representable, but it also created distinctions within the apparatus of protection.

\section{From Refugees to Farmers: Ordering through Work}

During the 1970s and 1980s, the UNHCR approach became enriched by new ways of thinking. Notions like work, development and economic integration came to play a larger role in the framing of aid programmes. This is not to say that these notions did not play a role before this period, but rather that their impact on programmes grew rapidly now. The conventional distinction between 'protection' (understood as a legal task) and 'solutions' (understood as longer-term, socially embedded projects) began to blur. While some UNHCR staff continued to uphold a narrow definition of protection limited to legal tasks (such as granting residence permits, travel documents or legal protection against arbitrary arrest; helping individuals become naturalized, etc.), others reframed protection based on the notion of development: the UNHCR Legal Protection division spoke of legal rights, while experts in the Assistance division spoke increasingly of 'material assistance', 'local integration' and 'zonal development' (Loescher 2000).

The notion of work was particularly important for Central African programmes, above all since international refugee law had revealed its limits in non-European contexts. Thanks to the notion of 'good offices', the UNHCR could justify its African programmes to the Executive Committee and General Assembly, thus bypassing the 1951 definition of refugee (Loescher 2000: 106-139). The UNHCR argued that material aid was instrumental to convincing African regimes to accept refugees. This line of argumentation linked 'material assistance' to 'protection', implying that African states would accept refugees within their territories, while UNHCR and Western donors would provide assistance. United Nations High Commissioner for 
Refugees Sadruddin Aga Khan argued that material assistance would 'encourage a generous asylum policy' (Pitterman 1984: 28). Of course, this was a double-edged sword: African states quickly made their willingness to protect refugees conditional upon aid from the international community - that is, unless the UNHCR and donor states were willing to pay for material aid, the African states would not tolerate refugees (Rutinwa 1999: 18; Hyndman 2001: 49).

Taking into account the notions of 'work' and 'development', however, was not just about expanding access. A second advantage was that it gave the UNHCR an idiom for addressing post-colonial African states. In the first decades after independence, there was much talk about economic growth and labour mobilization. African leaders made a tremendous effort to mobilize rural labour because they lacked the financial means to construct new infrastructures and provide services. Various forms of labour mobilization flourished: harambee in Kenya, salongo in Zaire, begakwabega in Tanzania, 'travaux de development communautaires' in Burundi, umuganda in Rwanda and so forth. Since capital and technology were scarce, high-intensity labour was seen as a gateway to development. Obligatory and unpaid work was a recurrent feature in development programmes in rural Africa. In Burundi, every adult was obliged to engage in community work every Saturday from 7 a.m. to 12 p.m. This free workforce was used to build and maintain roads, railways, schools, community centres and irrigated fields. Labour was thought to be abundant, and 'nation building' was given priority. As a result, even though labour mobilization was ambiguously related to the detested colonial compulsory labour, it became standard in nationalist toolboxes (Guichaoua 1991; Cooper 1996).

African leaders were not alone in talking about work and development-all of their partners did, too. United Nations agencies such as the Food and Agriculture Organization (FAO), the United Nations Development Programme (UNDP) and the World Bank all had concepts of development and labour (UNHCR 1970). By using similar language regarding work, the UNHCR was able to align its interests with those of bigger and more powerful international organizations. One source of inspiration was the expertise on migration of the International Labour Organization (ILO 1957). Labour migration 'was becoming the focus of concern that forced labour had once been' (Cooper 1996: 218). Migration was seen as causing moral decay, disrupting family life, destroying 'tribal' social structure, reducing moral support for workers and so on. UN experts saw the mobility of labour in Africa as 'abnormal' and disruptive of rural communities. They envisioned labour stabilization as a precondition for improved social security. Stabilization became a consensus among international organizations (Cooper 1996: 365). ILO experts encouraged village planning, family housing, social services and the improvement of rural living conditions - topics that were all familiar to the UNHCR. 
UNHCR experts realigned their 'protection' agenda with the interests of post-colonial developmentalism. This had the undertone of a moral project linking protection to work ethic: 'Material assistance,' deputed High Commissioner Prince Sadruddin Aga Khan wrote, 'is meaningful only when the recipients feel they are working hard and trying to establish themselves' (Goetz 2003: 11). At times, this vision was backed by optimistic faith in modernization and economic growth. 'The international effort for assistance to refugees,' declared the UNHCR's Felix Schnyder, 'could be regarded as a useful element in the field of international development aid. ${ }^{, 2}$ Refugees were seen not as a challenge for humanitarian aid, but as an opportunity for growth. According to one expert,

the presence of refugees can act as a catalyst for overall planning and development. Their arrival in a neighboring country can serve as a stimulus to programmes, sponsored and staffed by Africans and non-Africans alike, that strengthen and advance rural development (Matthews 1972: 82).

UNHCR consultants resurrected an old notion that had been used for Asia Minor refugees in Greece (1922), and in India and Pakistan (1948): the notion of 'refugee settlements'. The plan was to integrate refugees in their host country. The UNHCR linked the 50-year-old concept to trendy ILO terminology and to the World Bank concept of 'integrated rural development land settlement schemes', as well as to the 'new land settlement' ideas of USAID, and opened its first African rural settlement for Rwandans seeking refuge in Zaire in Bibwein 1962 (Kivu). ${ }^{24}$ The rural camps were based on agricultural activities and aimed for 'self-sufficiency'. The programmes included irrigation, drainage, as well as the building of roads, accommodations, schools and vocational centres. 'Rural settlements schemes' were seen not only as a solution for arriving refugees, but also as potential catalysts for rural development as a whole. One of the first reports on refugee settlement stated: 'The new settlements would thus become the centers of development for the whole area. ${ }^{25}$ In other words, it was thought that refugee settlements would contribute to economic planning. The strategy of 'zonal development' was implemented in Zaire, Burundi and Uganda, under cooperative agreements between the UNHCR, ILO, FAO and UNDP (Betts 1966).

Where the UNHCR had once provided refugees with travel documents and legal advice, it now gave them tools and seeds. As the number of refugees in the Central African region grew steadily, the importance of material assistance also rose. Between 1959 and 1966, some 200,000 Rwandans fled to Uganda, Burundi and Zaire. In 1980, there were 500,000 Rwandans in Uganda and somewhere between 800,000 and 1.4 million in Zaire (Guichaoua 2004: 119-120). The 1966 military coup and the 1972 pogroms against Hutu in Burundi also produced thousands of Burundi refugees fleeing to Zaire, Tanzania and Rwanda. In 1973-74, thousands of Tanzanians fled the authoritarian Ujamaa collectives. As a result: 'In every year from 1967 


\section{Glasman}

through 1973, African countries received more than half of all international refugee aid' (Pitterman 1984: 28). In the mid-1980s, almost all UNHCR money was spent on material assistance.

From 1961 to 1982, the UNHCR opened 107 settlements in Africa, assisting a total of 940,000 refugees (Clark and Stein 1985). Rural settlements had become the cornerstone of UNHCR policy regarding African refugees. A report noted:

It is in Africa that the major part of UNHCR's refugee problems are now to be found, and settlement in a rural environment is still the main solution to those problems (UNHCR 1970: 1).

In the 1980s, 96 per cent of the 111 organized refugee settlements in the world were in Africa (Clark and Stein 1985: 2). Both international conferences on Assistance to Refugees in Africa held in Geneva at the time-ICARA I in 1981 and ICARA II in 1984 -reaffirmed the role of local integration and the relevance of organized settlements.

Looking at the question of refugees through the prism of work gave the UNHCR a new way to grasp the issue. ${ }^{26}$ It translated a juridical and political problem ('protection') into an economic and social question ('self-sufficiency' and 'integration'). The link between refugee aid and labour consisted of a range of concrete tasks for refugees (draining marshland, cultivating arable land, constructing community centres and water supplies, building roads, etc.). However, it also exposed the UNHCR to new kinds of criticism. UNHCR experts could not hide behind legal determination and identification procedures; they had to engage in discussions about comparative soil quality, culture rotation, chemical fertilizers, poor harvests and tractors breaking down. Critics doubted the economic viability of refugee settlements. Unsurprisingly, the UNHCR assessed its own settlement policy positively. ${ }^{27}$ But the settlements experienced the same problems as other rural development projects: climate challenges, inconsistent soil fertility and lack of technology. In various cases, planning experts incorrectly estimated the adequacy of water resources or the quality of the soil.

A first criticism focused on the question of 'dependency'. In the eyes of some observers, UNHCR settlements not only failed to make refugees 'selfsufficient', but actually made them dependent on relief aid (Harvey and Lind 2005). Notoriously, anthropologist Barbara Harrell-Bond accused the UNHCR of fuelling the 'dependency syndrome' of refugees (Harrell-Bond 1986: 151).

A second criticism targeted the obsession with control in the settlements. Refugee settlements often looked like closed camps, limiting their occupants' departures and mobility (Clark and Stein 1985: 10). UNHCR settlement policy resonated with both Western governments' will to contain African refugees and African states' policies of monitoring foreign populations. Some studies argued that refugees living outside the camps were better off 
than those inside them (Kok 1989; Malkki 1995a; Van Damme 1995; Hansen 2001). Refugees, when they could, avoided living in camps (Davis 1992; Harrell-Bond and Voutira 1992; de Waal 1997). ${ }^{28}$

A third criticism was pointed at the political imagination of the UNHCR. Rural settlement programmes were accused of enforcing a sedentary view of societies that aimed for territorial permanence of populations at any price. For critics, refugee settlements seemed to be more about transforming migrants into farmers, townspeople into villagers and groups of refugees into 'communities' than about protecting refugees.

However, the prism of work gave rise to a new mode of classification. An entire new class of people now qualified for inclusion in UNHCR programmes: the 'host population'. This category was part of 'rural settlement schemes', 'regional approaches' and 'zonal development programmes' that emphasized the interests of local populations. ${ }^{29}$ UNHCR activities were no longer just about refugees and returnees, but now also considered peasants and their neighbours. A new terminology had emerged that informed programme planning and resource allocation: the terminology of productivity and development and of refugees' ability to become settlers. ${ }^{30}$ The best possible refugee for a 'rural settlement' programme was young and able, had farming experience and was willing to contribute to voluntary community work. The elderly, children and persons with disabilities were not the only ones considered more difficult to integrate; so, too, were bureaucrats, students and pastoralists, who were often described as unable or unwilling to adapt to farming. A conceptual opposition took shape, between 'rural refugee' (poorer, less educated, but more malleable and sedentary) ${ }^{31}$ and 'urban refugees' (more educated, mobile, living in a more expensive environment and more likely to be politicized). ${ }^{32}$ This opposition still informs many workrelated projects today (e.g. 'food for work' projects and 'Income Generating Activities'). The approach through law, legal protection and citizenship was complemented by an approach through work, living standards and communities.

\section{From Refugees to Patients: Ordering through Needs}

During the 1980s and 1990s, health specialists became increasingly involved in the UNHCR. The agency included not only lawyers and clerks, but also epidemiologists, paediatricians and nutritionists. Refugee societies were reframed through the prism of needs. People were classified not only according to their legal status, but also according to their vulnerability. Although the UNHCR made a formal distinction between 'material assistance' and 'protection', it became increasingly accepted that meeting refugees' immediate needs was an integral part of protection. ${ }^{33}$

This was a conceptual shift: old words gained new meaning. 'Basic needs', for example, was not a new term in the UNHCR vocabulary. But reports from the 1970s referred to 'basic needs' as being met by lawyers - through the 


\section{Glasman}

procedure of asylum, for example. ${ }^{34}$ Reports from the 1980 s talked about 'basic needs' with respect to rural labour in rural settlements and as a criticism of macroeconomic approaches (ILO 1976); 'basic needs' were a tool to combat poverty. ${ }^{35}$ Now, in the 1990s, 'basic needs' referred to the task of 'care and maintenance assistance' (UNHCR 1992). Today, the same notion refers to 'minimum standards' for aid, as defined by a broad range of experts in the areas of health, nutrition, education, shelter, water, sanitation and hygiene (UNHCR 2013: 38-42). Basic needs are now associated with immediate, life-saving services in emergency situations.

This also represented a material shift. Care and maintenance activities now use up the bulk of UNHCR funding for Africa (UNHCR 2015: 91-92). The evolution of refugee camps was emblematic for the emergence of a 'relief model'. Unlike settlements in the 1970s and 1980s, which were based on agricultural work and aimed to push foreign labourers towards local integration, the relief camps of the 1990s and 2000s were like hospitals, treating refugees as patients. Camps tended to be internationally managed and funded, and administrated separately from the surrounding population (Crisp 2006: 12). They relied increasingly on relief handouts and food distribution, and less on subsistence farming. Camps became places of population management, medical intervention and epidemiological analysis. As a result, they have sometimes been referred to as 'bio-political' sites of intervention (Agier 2002). ${ }^{36}$ Unlike the refugee settlements that gave refugees an opportunity to acquire land and earn a living, the new camps were sites of emergency relief and control.

The concept of needs emerged in a dual context. First, there was a change in asylum policies. For the first two decades or so following independence, African asylum policies were relatively generous. The 1969 OAU Convention established a liberal definition of refugees and made non-refoulement a norm (Crisp 2006: 2). During this period, refugees were rarely rejected at the border or forcibly returned to countries where they faced persecution. Many refugees benefited from a range of legal, social and economic rights in African states; they were offered land to settle and, in some cases, could hope to becomenaturalized. ${ }^{37}$ In the 1980s, however, this 'open-door' policy ended. Economic growth slowed or reversed, Structural Adjustment Programmes cut off public spending, official development assistance declined and northern powers introduced harsher asylum policies to prevent refugees from going north. The implicit deal between African states and the international community-generous asylum policies in exchange for material support-was broken. African states became increasingly reluctant to welcome refugees and repatriated them at the earliest opportunity (Rutinwa 1999).

The second development was a rising number of refugees. In 1970, there were one million refugees in Africa; by 1990, this figure stood at more than six million. The magnitude and rapidity of flight had changed. The numbers peaked in the aftermath of the Rwandan genocide. Between 14 and 18 July1994, around 850,000 Rwandans crossed the border to Zaire (Borton 
et al. 1996: 13). In the following two months, some three million Rwandans fled to Tanzania and Zaire (Mamdani 2002; Lischer 2005; Banégas and Chrétien 2009; Lemarchand 2009). The UNHCR described it as the fastest exodus it had ever witnessed (Rutinwa 1999: 16). Following this crisis, several African countries closed their borders. Instead of offering external protection, these states pushed for keeping escapees in 'safe areas' or 'safe zones' within their countries of origin. In 1996, Zaire closed its borders to Burundi refugees, and Tanzania required all Rwandan refugees to leave (Rutinwa 1999). The number of IDPs grew quickly.

The UNHCR refocused its aid on emergency relief. While it did not stop addressing rights and work issues, it increasingly set standards for urgent aid. First, it turned to food rations, logistics, water and sanitation, shelter, latrine seats and refuse bins (UNHCR 2000). The UNHCR codified emergency norms and guidelines, accumulated emergency stockpiles in Copenhagen and Dubai, and delivered tents, blankets and jerrycans to millions of refugees in dozens of countries. The delivery of basic needs and essential services now absorbs more than half (56 per cent) of the UNHCR budget (UNHCR 2015: 83).

Focusing on emergency relief gave UNHCR new opportunities. Just as the prism of work enabled the agency to address host populations and communities, the prism of needs helped it to rethink the targets of its aid. Instead of devoting itself solely to refugees, it now also attended to 'people of concern', including not just registered refugees, but also IDPs, expellees or returnees. Today, the UNHCR has declared 11 million 'people of concern' (UNHCR 2015), only one-third of which are refugees or asylum seekers. By expanding its original mandate and activities, the organization established itself as the 'lead agency' in humanitarian catastrophes, ${ }^{38}$ managing an archipelago of thousands of camps. ${ }^{39}$ The UNHCR reframed refugee protection as the 'global governance' of people in need (UNHCR 2011), offering care and support not only to refugees, but also to 'hungry, homeless and poor people worldwide' (Vibeke 2002: 102). ${ }^{40}$

Most of the vocabulary regarding needs was borrowed from other UN agencies (such as the World Food Programme, the World Health Organization and United Nations Children's Fund; UNICEF) and humanitarian NGOs. The International Committee of the Red Cross (ICRC) has a long tradition of humanitarian law, which makes it possible to address the question of war victims. The 1949 Geneva Convention distinguishes 'combatants' from 'non-combatants' and offers a classification of vulnerable people that goes beyond 'refugees'. More importantly, NGOs such as Oxfam, Save the Children and Médecins sans frontières have all developed tools to prioritize the medical needs of aid recipients (Redfield 2013; Scott-Smith 2013). Unlike conventional UNHCR 'screening' of refugees, which seeks to determine people's legal status, the logic of 'triage' used by humanitarian organizations compares bodies and types of pain in order to establish medical priorities. 


\section{Glasman}

Indeed, sorting populations in terms of need was inspired by the notion of 'triage' used in emergency medicine. ${ }^{41}$ Due to the scarcity of resources, the UNHCR learned to classify individuals based on the priorities used in medicine (Lachenal et al. 2014). New criteria for action were adopted, based on epidemiology and demographics. 'Protection' now integrated indicators such as mortality rates, nutritional status and morbidity, as well as specific attention to high mortality diseases like cholera. Unlike the conventional approach to protection, which targeted refugees, the humanitarian approach now targeted 'humans' (Geissler et al. 2012: 8). Cooperation between the UNHCR and medical NGOs fostered the discourse on 'global health' and 'global needs'.

This new perspective once again exposed the agency to new criticism. The relief model was accused of being short-sighted. Relief aid in camps has been criticized from an epidemiological perspective (Van Damme 1995), but also for its blindness to political side effects. Refugee camps have been accused of restricting refugees' freedom of movement, favouring undemocratic modes of governance, reducing refugee participation and ultimately endangering protection. Refugee camps have been the target of military attacks (Burundi camps in Tanzania and Sudanese camps in Chad, for example, have been attacked on several occasions) and the site of various forms of violence (from coercion to crime, including domestic violence, armed robbery, forced conscription, sexual violence, arbitrary arrest, etc.) (Crisp 2006: 6). As a result, camps have become emblematic of biomedical migration control. ${ }^{42}$ To underscore the dehumanizing effects of refugee relief, scholars have compared camps to prisons, psychiatric institutions and even concentration camps (Agamben 2002; Agier 2002; Inhetveen 2010; Jaji 2011).

However, the UNHCR has increasingly embraced the classification of people according to their needs and vulnerabilities. UNHCR activities have been reoriented to address 'people with disabilities', 'chronically ill persons', 'unaccompanied children', 'the elderly', 'teenage mothers', 'single heads of household', 'caregivers', 'survivors of rape' and so on. Beyond merely designating target groups, these categories have also become statistical categories (Tallio 2007; Cambrezy 2007). ${ }^{43}$

\section{Conclusion}

Most of the people gathered on the football field in Kenzou eventually obtained refugee status based on prima facie procedure. ${ }^{44}$ They were transported by truck to nearby refugee camps in Timangolo, Mbilé and Lolo. Classifications shaped their experience of camp life. They brought with them the papers issued by the UNHCR - identity documents and ration cards - which entitled them to relief aid. Based on these documents, aid workers handed out plastic sheets, blankets, kitchen sets, jerry cans, soap and food rations. Priority access was given to family tents for women who were single heads of households; to supplementary food for children under five; to 
sanitary pads for girls over the age of 11 years; to kitchen sets for members of large households; and so on. Camp life was managed according to the logic of classification. Humanitarian organizations are 'inveterate classifiers' (Fourcade and Healy 2013: 562): not only do they distinguish between people who are included in their categories and those who are not, but they also stratify each group along a sliding scale of needs.

Since humanitarian stakeholders often present 'protection' as a unified field of intervention, the plurality of the types of logic involved tend to be overlooked. This idealistic vision is reinforced by the fact that the same word, 'protection', is used to refer to an idea (the moral impetus of treating refugees with decency), a body of legal procedures (framed by international refugee law) and specific institutional boundaries (the UNHCR Division of International Protection, 'protection officers', 'protection assistants', 'protection clerks', etc.). This is why the history of refugee protection tends to be written in linear terms, with ups and downs, moments of progress and crisis, potential and missed opportunities. The conventional narrative presents protection as a cursor on a moral ladder; we follow protected refugees the same way traders follow market prices, anxiously watching stock charts.

But refugee protection is not a one-dimensional process. Indeed, its success may be linked to the very malleability of the notion. Paradoxically, the more the UNHCR has come to reframe the question of migration through the prism of international refugee law, the more it has also engaged with other modes of ordering refugees. As this article shows, though current refugee classifications articulate different modes of ordering, each one has its own inherent logic, history and materiality. The framework of international law was established for European refugees in the aftermath of World War II and had to be adapted to non-European settings. The framework of development and work emerged to enable engagement with African states and development organizations - UNDP, World Bank, ILO, etc.-after decolonization. Finally, the framework of needs and vulnerability became increasingly relevant as the number of refugees rose at the end of the twentieth century, since it allowed humanitarian actors-WFP, WHO, ICRC, MSF, Oxfam, etc.- to become involved. Each mode of ordering corresponded to an attempt to make a new situation legible and to engage with new partners.

In James Scott's study, the notion of 'legibility' is backed by a second notion: 'high modernism'. This term designates the ideology of the modern state and its uncritical self-confidence regarding scientific and technical progress, production and rationality. According to Scott, high modernist planners share an uncritical optimism regarding comprehensive planning and the efficiency of social regimentation. At times, the literature on refugee camps (especially that which draws on Foucault's notion of biopower or Agamben's 'naked life' terminology) tends to treat UNHCR planners as high modernists because of their taste for grid-designed camps, clear boundaries and rigid order (Godding 1997; Herz 2012). 


\section{Glasman}

However, Scott studied highly centralized and often authoritarian states such as Prussia, the Soviet Union and socialist Tanzania-bodies that are light-years away from international organizations. The one characteristic that the UNHCR might be said to share with the modern states observed by Scott is the failure to consult the 'people of concern' regarding classification mechanisms. ${ }^{45}$ However, UNHCR modes of action are not those of the modern centralized state, because the UNHCR is neither a state nor centralized. With a staff/person-of-concern ratio of 1:5,020 (UNHCR 2015), the UNHCR is a weak institution with a large mandate. It acts in a decentralized and fragmentary manner through a range of other actors - states of varying sizes and strength, UN agencies with different mandates, NGOs with diverse interests, refugees committees with varying representation and so on. ${ }^{46}$ Its actions are embedded not in a unified and coherent vision of protection, but in a stratified world of asymmetrical cooperation and distinct solutions. If anything, the UNHCR is more about high connectivity than high modernity. As a result, the strength of the UNHCR is the result not so much of its means of protection as of the quasi-monopoly it holds over the means of classification.

\section{Acknowledgements}

I am thankful to Roseline Okoro, UNHCR Protection Officer in Yaounde, to Jean Yougouda and the 22 UNHCR staff members and partners (ACF, MSF, UNICEF, WFP, Croix-Rouge) who introduced me to the world of refugee protection in Cameroon in 2014, as well as to the presidents of the 'Comités des réfugiés' in Kenzou and Lolo and refugees who agreed to answer my questions. Their views greatly inform this article. I am also grateful to Julia Eichenberg, Stefan Hoffmann, Olaf Kleist, Agathe Menetrier, Jill Pöggel, Sophie Schlondorff and the anonymous peer reviewers of the Journal for their comments on an earlier version of this text.

1. Technically speaking, the United Nations High Commissioner for Refugees (UNHCR) is not an agency according to United Nations terminology. However, for the sake of simplicity, I will use this denomination here.

2. The UNHCR Handbook for Registration defines 'refugee registration' as 'the recording, verifying, and updating of information on persons of concern to UNHCR with the aim of protecting and documenting them and of implementing durable solutions' (UNHCR 2003: 6).

3. For an analysis of the situation in the Central African Republic, see ICG (2014).

4. UNHCR, Annual Reports, Geneva, 1951-2014.

5. The notion of 'black box' is borrowed from Latour (1989).

6. UNHCR Regional Update 46: Central African Republic Situation, 27 December 2014-16 January 2015. The report counted a total 864,515 people of concern, 425,977 of whom were refugees (including 189,802 new Central African Republic refugees in neighbouring countries since December 2013).

7. Name changed. 
8. Among the organizations assisting refugees in Cameroon (besides state institutions such as the Ministry of Basic Education, Public Health, Social Affairs, etc.) were several UN agencies (International Organization for Migration (IOM), UNICEF, UNFPA, UN Women, WHO, WFP) and many NGOs (including the French Action Contre la Faim, the US-American Adventist Development and Relief Agency, the Ethiopian Africa Humanitarian Action, the Cameroonian CroixRouge, the French Croix-Rouge and the Swiss Branch of Médecins Sans Frontières).

9. The UNHCR assists refugees, who are not protected by their state of origin, while the IOM assists migrants, who are still protected by their state of origin. In Kenzou, the IOM ran small camps for people who had fled from the Central African Republic, but had another nationality (i.e. they were neither Central African nor Cameroonian, but from Mali, Niger, Chad, etc.) and helped migrants return to their country of origin. However, since many people had lost their documents while fleeing and international migration is frequent in this context, it was not easy to determine which category applied. Several people at the registration desk in Kenzou attempted to obtain both statuses, because they did not yet know which would be the best option - to be a refugee or a migrant. Also, some Cameroonians applied for refugee status in Cameroon, arguing that they were from the Central African Republic. Refugee status would give them access to UNHCR aid.

10. This typology is based on the reading of secondary sources (listed in the footnotes) as well as on UNHCR grey literature, including UNHCR Reports to the General Assembly and reports from UNHCR Archives, especially: Reports on Central Africa from Fonds 18/Records relating to Assistance/Sub-fonds 2: General technical services Series; UNHCR Headquarter Archives: Report on Central Africa from Fonds 11/Series 02 Classified Subject Files 1971-1984; and UNHCR Handbooks for Emergencies (1982, 2007).

11. This distinction between those who protect and those who are protected is illustrated by the omnipresence of ballistic metaphors in refugee protection ('target population', 'project impact', etc.).

12. The 'modes of ordering' explored in this article are not unlike the 'regimes of truth' in Foucault (2004 [1979]) sense, 'modes of existence' in Latour's (2012) sense and 'modes of doing good' (Boltanksi and Thévenot 1991; Pols 2003).

13. Farmers practising shifting cultivation, herders seeking fertile lands, merchants trading with the coast, etc. In the densely populated kingdoms of the Great Lakes region, demographic growth regularly triggered agricultural expansion. In lineage-based societies, when groups grew big, political organizations would splinter: a segment of the lineage would leave the settlement and establish a new compound, hamlet or chieftaincy. Migration was entrenched in a 'logic of schism', itself fuelled by low population density and the perceived abundance of land (Kopytoff 1987).

14. A French administrator of Ubangi-Shari complained about the 'massive exodus' from his circumscription. 'Everyone,' he wrote, 'abandons his tribe, his village, his family and plantations, goes to live in the bush like a hunted animal, to escape from recruiters.' Cf. Administrative Report on Ubangi-Shari, 1902, quoted in Gide (1927: 89-90, translation JG).

15. Colonial administrators attempted to control migration by grouping villages along roads, aggregating populations according to ethnic blocs and establishing fixed 
territorial boundaries. Also, they often encamped migrant populations (in mining camps in the copper belt of Katanga and Rhodesia, in concentration camps in Cameroon and Kenya, in medical camps in Congo, in disciplinary camps in Gabon and so on (Asiwaju 1976; Scott 1998; Bernault 1999)).

16. 'Where are they going? Far, very far. A one week travel is for them an ordinary thing. ... The men walk, the women walk, the children walk.... They are crossing Africa like we cross from one pavement to another' (Londres 2008 [1929]: 30).

17. The notion of 'good office' was first used for Hong Kong in 1957 (Hyndman 2001).

18. Resolution 1673 (XVI) of the UN General Assembly on 18 December 1961.

19. In 1961, the 80 professional UNHCR staff members were mainly British, French and American, with little or no experience in Africa. There was no staff from Africa or Asia (Loescher 2000: 109).

20. Burundians spoke of 'kurobera' ('disappearing for a moment').

21. 'Now that the big assistance programmes for European refugees are nearing completion, legal protection, as defined and elaborated in the Statute of the High Commissioner's Office, is on the way to becoming once more our main concern so far as these refugees are concerned. On the other hand, the problem raised by the new groups of refugees to which my attention was drawn some time ago, is essentially, at the moment, a problem of material assistance and not of legal protection. ... I must emphasize, however, that there cannot be any true relationship between the terms of this two-fold development, both on the factual and the legal plane, or any necessary and exclusive link between the mandate and the "old refugees" on the one hand, and good offices and the "new refugees" on the other. What is important is that the work of this Office should be constantly adapted to the needs it has to meet.' Introductory statement by Mr Felix Schnyder, UNHCR, to the Executive Committee of High Commissioner's Programme, sixth session, Geneva, 6 November 1961. Statements by High Commissioner, 22 November 1961.

22. Convention Relating to the Status of Refugees, 1951, Article 1.

23. Felix Schnyder, Report on New Refugee Situations, submitted to the 7th session of Excom (1962), UN Doc A/AC.96/158), quoted by Loescher (2000: 121).

24. In the 1960s, in the Central African region, the UNHCR opened new settlements in Burundi (Kigamba, Kayongasi, Muramba, Mujera), the Central African Republic (Mboki, Mutara), Tanzania (Karagwe, Muyenzi, Mwesi, Rutamba, Lundo Muhukuru, Matekwe, Mputa, Katumba, Ulyankulu, Kigwa, Pangale), Zaire (Ihula, Bibwe, Kalonge, Mutambala, Amadi, Kypo, Kaniama) and Uganda (Oruchinga, Nakivale, Kahunge, Rwamwanja, Kyaka, Ibuga, Kyangwali, Agago).

25. UNHCR, Summary Report on the Refugee Problem in the Republic of Togo. HCR/RS/23IRev.1. Geneva: UNHCR, February 1962: 5. Quoted in Pitterman (1984: 44).

26. UNHCR Fonds 11/Series 02/592 Assistance Specialist Support Unit Rural Settlements Planning and Evaluation 1984/198411.02./0908.

27. 'On the whole, the results obtained in the sphere of rural settlement in Africa are satisfactory, since the vast majority of the refugees have already been restored to living conditions which, in comparison with those of the local inhabitants themselves, are practically normal' (UNHCR 1970, p. 2). 
28. In the mid-1980s, Clark and Stein estimated that half of all African refugees were 'spontaneously settled'. One-quarter lived in 'relief or post-relief refugee camps' where they were dependent on food rations and other international assistance, and one-quarter lived in 'organized settlements' (Clark and Stein 1985: 2).

29. For an early description of 'zonal development', see UNHCR 11 Series 04 EA Kivu 1-2. Emergency assistance to refugees from Rwanda 1964-1966.

30. In refugee settlement surveys, for instance, particular attention was given to refugees' agricultural and occupational background (the type of crops they had grown, agricultural systems they knew, etc.). See UNHCR, Planning Rural Settlements for Refugees: Some Considerations and Ideas (1979).

31. Hyndman and Giles (2011) speak of the 'feminization' of sedentary settled refugees who represent no threat, as compared to refugees or migrants 'on the move'.

32. Refugees have to declare themselves 'autonomous' or 'self-sufficient' to become urban refugees in UNHCR terminology. From that point on, they forfeit all material assistance (except punctual assistance for the most 'vulnerable' and medical assistance).

33. 'Ensuring protection and providing humanitarian assistance are not two separate issues. Rather, humanitarian assistance is an integral part of protection and should be planned to ensure that the rights of refugees and others of concern are respected (right to life, right to adequate living conditions, protection of specific categories of people such as older persons, unaccompanied and separated children, single parents, survivors of SGBV etc.) and as part of a single emergency operation.' (UNHCR 2007: XI).

34. 'The developments described in this chapter, like international protection itself, are in the main concerned with three basic needs of the refugee: to receive asylum; to be granted a satisfactory legal status in the reception country; and to be able to cease to be a refugee through voluntary repatriation or, if this is not possible in the foreseeable future, by the acquisition of the nationality of his country of residence' (UNHCR 1970: 4).

35. Bakhet Omar, 'The Basic Needs Approach (BNA) to Self-sufficiency in Rural Refugee Settlements', in Managing Rural Settlements for Refugees in Africa: Proceedings of a Workshop on the Follow-Up to Arusha Recommendations on Rural Refugees in Africa, UNHCR, Dar es Salaam, September 1981, 145-164.

36. For a critique of the term 'biopolitic', see Geissler et al. (2012).

37. Integration through work was considered a sustainable option. In countries like Tanzania or Uganda, many refugees could access the job market and even high positions in the civil and diplomatic services (Rutinwa 1999: 8). The discourse on African solidarity against foreign oppression (especially for refugees fleeing wars of national liberation in Angola, Rhodesia, South Africa, South-West Africa and Mozambique) contributed to the generous asylum policy. However, the 'opendoor' policy should not be idealized, as refugees were often required to remain in camps and, in some notable cases, refoulement and forced repatriation were practised.

38. There is fierce competition for coordination of humanitarian activities. UNICEF, the World Food Programme and the Office for the Coordination of Humanitarian Affairs (OCHA) are serious candidates for the role, but the influence of UNHCR is growing (Weiss 2002).

39. The UNHCR is present in every single country in Africa. It has offices in 123 countries worldwide and in 449 locations. 


\section{Glasman}

40. The UNHCR distributed kitchen sets to earthquake survivors in Haiti (2010), blankets to flood victims in Pakistan (2010) and tents to Typhoon escapees in the Philippines (2013) - its current activities go far beyond legal protection of refugees and even encompass material aid in natural disaster settings.

41. The medical term 'triage' (also sometimes called 'rationing' and 'allocation') refers to the distribution of medical resources to patients. The World Medical Association, for example, recommends a four-class typology-red/immediate: those whose lives are in immediate danger; yellow/delayed: those who need urgent but not immediate medical care; green/minimal: those who require only minor treatment; black/expectant: those who cannot be saved.

42. A good example of the critical perspective on camps is given by Hyndman: '[Camps are] sites of neo-colonial power relations where refugees are countered, their movements monitored and mapped, their daily routines disciplined and routinized by the institutional machinery of refugee relief agencies' (Hyndman 1997: 17).

43. In the early 1980s, Harrell-Bond criticized the notion of 'vulnerability' on economic grounds. For her, 'vulnerable' groups are all people who do not achieve economic autonomy 'for whatever reason' (Harrell-Bond 1986: xiv). Today, the critique of 'vulnerability' is directed much more at biomedical criteria. Here again, it is striking that criticism of the UNHCR itself is shaped by the institutional understanding of classifications.

44. Some did not. UNHCR staff refused some of the applicants - those who said they were born in Cameroonian villages and were thus classified as 'Cameroonian citizens' (and as a result could not be considered 'refugees' in their own country), for example. One group of Cameroonians applied for refugee status in Kenzou by stating that they flew from Boko Haram in northern Cameroon (obviously unaware of the differences between IDPs and refugees in international law).

45. The silencing of victims has been well studied by anthropologists (Malkki 1995a; Harrell-Bond 1986; Agier 2002).

46. For a conclusive description of the UNHCR's decentralized bureaucracy, see Scalettaris (2013).

AGAMBEN, G. (2002) Homo sacer. Die souveräne Macht und das nackte Leben. Frankfurt a.M: Suhrkamp.

AGIER, M. (2002) 'Between War and City: Towards an Urban Anthropology of Refugee Camps', Ethnography 3: 31-341.

AGIER, M. (2008) Gérer les indésirables: Des camps de réfugiés au gouvernement humanitaire. Paris: Flammarion.

ASIWAJU, A. (1976) 'Migrations as Revolt: The Example of the Ivory Coast and the Upper Volta before 1945'. Journal of African History 17(4): 577-594.

BANÉGAS, R. and CHRÉTIEN, J. P. (eds) (2009) The Recurring Great Lakes Crisis: Identity, Violence and Power. New York: Columbia University Press.

BARNETT, M. N. (2011) Empire of Humanity: A History of Humanitarianism. Ithaca: Cornell University Press.

BernaUlT, F. (1999) Enfermement, Prison et Chatiments en Afrique. Du 19ème siècle à nos jours. Paris: Karthala.

BETTS, T. F. (1966) 'Zonal Rural Development in Africa'. Journal of Modern African Studies 7(1): $149-153$. 
BOLTANSKI, L. and THÉVENOT, L. (1991) De la justification: Les économies de la grandeur. Paris: Gallimard.

BORTON, J., BRUSSET, E. AND HALLAM, A. (1996) Joint Evaluation of Emergency Assistance to Rwanda. The International Response to Conflict and Genocide: Lessons from the Rwanda Experience. Study 3: Humanitarian Aid and Effects.

BOURDIEU, P. (1979) La distinction: Critique sociale du jugement de goût, le Sens commun. Paris: Éditions de Minuit.

CAMBREZY, L. (2007) 'Réfugiés et migrants en Afrique: quel statut pour quelle vulnérabilité?', Revue européenne des migrations internationales, 23(3): 2-13.

CHRETIEN, J. P. (1978) 'Des sédentaires devenus migrants, les motifs des départs des Burundais et des Rwandais vers l'Uganda (1920-1960)', Culture et dévelopement, X(I): 70-101.

CHRÉTIEN, J.-P. (2000) L'Afrique des Grands Lacs: Deux mille ans d'histoire. Paris: Flammarion.

CLARK, L. and STEIN, B. (1985) Older Refugee Settlements in Africa. Report of the Refugee Policy Group. Geneva: UNHCR.

COOPER, F. (1996) Decolonization and African Society: The Labor Question in French and British Africa. Cambridge: Cambridge University Press.

CORBET, A. (2008) Nés dans les camps. Changements identitaires de la nouvelle génération de réfugiés sahraouis et transformation des camps. Paris: TERRA-HN.

CORDELL, D. and PEROUSE DE MONTCLOS, M. A. (2002) 'Des "réfugiés" dans l'Afrique précoloniale? L'exemple de la Centrafrique, 1850-1910'. Politiqueafricaine 1(85): 16-28.

CRISP, J. (2006) 'Forced Displacement in Africa: Dimensions, Difficulties and Policy Directions'. New Issues in Refuge Research, Research Paper 126. Geneva: UNHCR.

DAVIS, J. (1992) 'The Anthropology of Suffering'. Journal of Refugee Studies 5(2): 149-161.

DE WAAL, A. (1997) Famine Crimes: Politics and the Disaster Relief Industry in Africa. Oxford: Oxford University Press.

DEDENIS, J. (2006) 'La territorialité de l'espace des camps de réfugiés sahraouis en Algérie'. Bulletin de l'Association des géographes français 1: 22-34.

FOUCAULT, M. (2004) Naissance de la biopolitique : Cours au Collège de France (1978-1979) In Senellart, M. G. (ed.) Paris: Seuil.

FOURCADE, M. and HEALY, K. (2013) 'Classification situations: Life-chances in the neoliberal era', Accounting, Organizations and Society 38: 559-572.

FRESIA, M. (2002) 'Aide humanitaire et production de services publics en Afrique de l'Ouest: le cas de la gestion des populations mauritanniennes réfugiées au Sénégal'. Buletin de l'APAD, 2002: $23-34$.

GATRELL, P. (2013) The Making of the Modern Refugee. Oxford: Oxford University Press.

GEISSLER, P.W. ROTTENBURG R. and ZENKER, J. (eds) (2012) '21st century African biopolitics: Fuzzy fringes, cracks and undersides, neglected backwaters, and returning politics'. In Geissler, P. W., Rottenburg, R. and Zenker, J. (eds) Rethinking Biomedicine and Governance in Africa. Contributions from Anthropology, Transkript, Bielefeld, pp. 7-19.

GIDE, A. (2010 [1927]) Voyage au Congo. Paris: Gallimard.

GODDING, J. P. (1997) 'Refugees or Hostages? Population Movements in the Great Lakes Region since 1990'. Unpublished conference paper, Oxford Social Sciences Library.

GOETZ, N. H. (2003) 'Towards self sufficiency and integration: a historical evaluation of assistance programmes for Rwandese refugees in Burundi, 1962-1965'. New issues in refugee research, Working paper 87 . Geneva: UNHCR.

GUICHAOUA, A. (1991) 'Les travaux communautaires en Afrique centrale'. Tiers Monde 32: 551-573.

GUICHAOUA, A. (2004) 'Migrants, réfugiés et déplacés en Afrique centrale et orientale'. In Guichaoua, A. (ed.) Exilés, réfugiés, déplacés en Afrique centrale et orientale. Paris: Karthala, pp. 105-212.

HAMMERSTAD, A. (2004) The Rise and Decline of a Global Security Actor. UNHCR, Refugee Protection \& Security. Oxford: Oxford University Press. 


\section{Glasman}

HANHIMÄKI, J. and ELIE, J. B. (2008) 'UNHCR and Decolonization in Africa: Expansion and Emancipation, 1950s to 1970s'. ArchivfürSozialgeschichte 48: 53-72.

HANSEN, A. (2001) 'Angolan Refugee Displacement and Settlement in Zaire and Zambia'. In De Wet, C. J. and Fox, R. C. (eds) Transforming Settlement in Southern Africa. Edinburgh: Edinburgh University Press, pp. 30-47.

HARMS, R. (1981) River of Wealth, River of Sorrow, the Central Zaire Basin in the Era of the Salve and Ivory Trade, 1500-1891. New Haven: Yale University Press.

HARRELL-BOND, B. (1986) Imposing Aid: Emergency Assistance to Refugees. Oxford: Oxford University Press.

HARRELL-BOND, B. and VOUTIRA, E. (1992) 'Anthropology and the Study of Refugees'. Anthropology Today 8(4): 6-10.

HARVEY, P., LIND, J. (2005) Dependency and humanitarian relief. A critical analysis, Humanitarian Policy Group Research Report, 19, 2005.

HATHAWAY, J. C. and FOSTER, M. (2014) The Law of Refugee Status. Cambridge: Cambridge University Press.

HERZ, M. (ed.) (2012) From Camp to City: Refugee Camps of the Western Sahara. Zurich: Lars Müller.

HOLBORN, L. W. (1975) Refugees: A Problem of Our Time: The Work of The United Nations High Commissioner for Refugees, 1951-1972. Metuchen: Scarecrow Press.

HYNDMAN, J. (1997) 'Refugee Self-management and the Question of Governance'. Refuge 16(2): 16-22.

HYNDMAN, J. (2000) Managing Displacement: Refugees and the Politics of Humanitarianism. Minneapolis: Minnesota University Press.

HYNDMAN, J. (2001) 'Change and Challenge at UNHCR: A Retrospective of the Past Fifty Years'. Refuge 19(6): 45-53.

HYNDMAN, J. and GILES, W. (2011) 'Waiting for What? The Feminization of Asylum in Protracted Situations'. Gender, Place \& Culture 18(3): 361-379.

INHETVEEN, K. (2010) Die politische Ordnung des Flüchtlingslagers: Akteure-MachtOrganisation: eine Ethnographie im südlichen Afrika. Bielefeld: Transcript.

INTERNATIONAL LABOUR ORGANIZATION (ILO) (1957) 'Interterritorial Migrations of Africans South of the Sahara'. International Labour Review 76: 292-310.

INTERNATIONAL LABOUR ORGANISATION (ILO) (1976) Employment, Growth and Basic Needs: A One-world Problem. Geneva: ILO.

JAJI, R. (2011) 'Social Technology and Refugee Encampment in Kenya'. Journal of Refugee Studies 25(2): 221-238.

JANSEN, B. (2011) The Accidental City. Violence, Economy and Humanitarianism in Kakuma Refugee Camp, Kenya. Thesis of Wageningen University, 2011.

KOK, W. (1989) 'Self-settled Refugees and the Socio-economic Impact of Their Presence on Kassala, Eastern Sudan'. Journal of Refugee Studies 2(4): 419-440.

KOPYTOFF, I. (1987) The African Frontier: The Reproduction of Traditional African Society. Bloomington: Indiana University Press.

LACHENAL, G., LEFÈVE, C. and NGUYEN, V. K. (2014) 'Le triage en médecine, une routine d'exception'. In Lachenal, G., Lefève, C. and Nguyen, V.-K. (eds) La médecine du tri: Histoire, éthique, anthropologie. Paris: Presses Universitaires de France.

LATOUR, B. (1989) La science en action: Introduction à la sociologie des sciences. Paris: Editions La Découverte.

LATOUR, B. (2012) Enquête sur les modes d'existence: une anthropologie des modernes. Paris: Editions La Découverte.

LEMARCHAND, R. (2009) The Dynamics of Violence in Central Africa. Philadelphia: University of Pennsylvania Press.

LISCHER, S. K. (2005) Dangerous Sanctuaries. Refugee Camps, Civil War, and the Dilemmas of Humanitarian Aid. London.

LOESCHER, G. (2000) The UNHCR and World Politics: A Perilous Path. Oxford: Oxford University Press. 
LONDRES, A. (2008 [1929]) Terre d'Ébène. Paris: Arléa.

MALKKI, L. (1995a) Purity and Exile: Violence, Memory and National Cosmology among Hutu Refugees in Tanzania. Chicago: Chicago University Press.

MALKKI, L. (1995b) 'Refugees and Exile: From "Refugee Studies" to the National Order of Things'. Annual Review of Anthropology 24: 495-523.

MAMDANI, M. (2002) When Victims become Killers: Colonialism, Nativism, and the Genocide in Rwanda. Princeton: Princeton University Press.

MATTHEWS, R. O. (1972) 'Refugee and Stability in Africa', International Organization, 26(1): $62-83$.

NOIRIEL, G. (1991) La tyrannie du National: Le droit d'asile en Europe (1793-1993). Paris: Calmann Levy.

ОКОТН-ОВвО, G. (2001) 'Thirty Years On: A Legal Review of the 1969 OAU Refugee Convention Governing the Specific Aspects of Refugee Problems in Africa'. Refugee Survey Quarterly 20(1): 118-122.

PITTERMAN, S. (1984) 'A Comparative Survey of Two Decades of International Assistance to Refugees in Africa', Africa Today 31(1): 25-54.

POLS, J. (2003) 'Enforcing Patient Rights or Improving Care? The Interference of Two Modes of Doing Good in Mental Health Care'. Sociology of Health \& Illness 25(3): 320-347.

REDFIELD, P. (2013) Life in Crisis: The Ethical Journey of Doctors without Borders. Berkeley: University of California Press.

RINGEL, S. (2011) Désirs et croyances dans l'aide humanitaire: Actions dans les camps de réfugiés $d u$ HCR à l'est du Tchad. Saarbrucken: Editions universitaireseuropeennes.

RUTINWA, B. (1999) 'The End of Asylum? The Changing Nature of Refugee Policies in Africa', New Issues in Refugee Research, Working Paper nr.5, May 1999.

RUTINWA, B. (2002) 'Prima Facie Status and Refugee Protection'. New Issues in Refugee Research, Working Paper No. 69.

SCALETTARIS, G. (2013) 'La fabrique du gouvernement international des réfugiés: Bureaugraphie du HCR dans la crise afghane'. PhD, EHESS, Paris.

SCOTT, J. (1998) Seeing Like a State: How Certain Schemes to Improve Human Condition Have Failed. New Haven: Yale University Press.

SCOTT-SMITH, T. (2013) 'The fetishism of humanitarian objects and the management of malnutrition in emergencies', Third World Quarterly 34(5): 913-928.

SHARPE, M. (2012) 'The 1969 African Refugee Convention: Innovations, Misconceptions, and Omissions'. McGill Law Journal 58(1): 17-19.

TALLIO, V. (2007) La fabrique du réfugié: L'exemple des camps de réfugiés de Dadaab (Kenya) et de Nkondo (RDC). Paris: Thèse EHESS.

TURNER, S. (2010) Politics of Innocence: Hutu Identity, Conflict and Camp Life. New York: Berghahn Books.

UNITED NATIONS HIGH COMMISSIONER FOR REFUGEES (UNHCR) (1970) Report the General Assembly, 25th Session. Geneva: UNHCR.

UNITED NATIONS HIGH COMMISSIONER FOR REFUGEES (UNHCR) (1979) Planning Rural Settlements for Refugees: Some Considerations and Ideas, Geneva: UNHCR.

UNITED NATIONS HIGH COMMISSIONER FOR REFUGEES (UNHCR) (1992) Report to the General Assembly, Official Records Forty-seventh Session, United Nations, New York.

UNITED NATIONS HIGH COMMISSIONER FOR REFUGEES (UNHCR) (2000) Les réfugiés dans le monde: Cinquanteansd'actionhumanitaire. Geneva: UNHCR.

UNITED NATIONS HIGH COMMISSIONER FOR REFUGEES (UNHCR) (2000 [1982]) Handbook for Emergencies. Geneva: UNHCR.

UNITED NATIONS HIGH COMMISSIONER FOR REFUGEES (UNHCR) (2003) Handbook for Registration, Procedures and Standards for Registration, Population Data Management and Documentation. Geneva.

UNITED NATIONS HIGH COMMISSIONER FOR REFUGEES (UNHCR) (2007) Handbook for Emergencies, Geneva, 1st Edition edn. 1982, 3rd edition 2007. 


\section{Glasman}

UNITED NATIONS HIGH COMMISSIONER FOR REFUGEES (UNHCR) (2013) Handbook for Registration, Procedures and Standards for Registration, Population Data Management and Documentation, Geneva: UNHCR.

UNITED NATIONS HIGH COMMISSIONER FOR REFUGEES (UNHCR) (2011) Global Trends 2010. Geneva: UNHCR.

UNITED NATIONS HIGH COMMISSIONER FOR REFUGEES (UNHCR) (2013) Report of the Executive Committee of the Programme of the United Nations High Commissioner for Refugees. Geneva: UNHCR.

UNITED NATIONS HIGH COMMISSIONER FOR REFUGEES (UNHCR) (2015) Global Appeal 2014-2015. Geneva: UNHCR.

VAN DAMME, W. (1995) 'Do Refugees Belong in Camps? Experiences from Goma and Guinea'. Lancet 346: 360-362.

VIBEKE, E. A. (2002) Mass Refugee Influx and the Limits of Public International Law. The Hague; London; New York: Martinus Nijhoff Publishers.

WEISS, T. (2002) 'UNHCR Should Lead the International Humanitarian Enterprise'. NIRA Paper. 